Abstracta Iranica Abstracta Iranica

Revue bibliographique pour le domaine irano-aryen

Volume 31 | 2011

Comptes rendus des publications de 2008

\title{
From Qajar to Pahlavi. Iran 1919-1930. Lanham, MD, University Press of America, 2008, 462 p., index.
}

\section{Bianca Devos}

\section{OpenEdition}

9 Journals

Édition électronique

URL : http://journals.openedition.org/abstractairanica/39598

DOI : 10.4000/abstractairanica.39598

ISSN : 1961-960X

\section{Éditeur :}

CNRS (UMR 7528 Mondes iraniens et indiens), Éditions de l'IFRI

\section{Édition imprimée}

Date de publication : 15 mai 2011

ISSN : 0240-8910

\section{Référence électronique}

Bianca Devos, «From Qajar to Pahlavi. Iran 1919-1930. Lanham, MD, University Press of America, 2008, 462 p., index. », Abstracta Iranica [En ligne], Volume 31 | 2011, document 178, mis en ligne le 11 octobre 2012, consulté le 27 septembre 2020. URL : http://journals.openedition.org/abstractairanica/39598 ; DOI : https://doi.org/10.4000/abstractairanica.39598

Ce document a été généré automatiquement le 27 septembre 2020.

Tous droits réservés 


\title{
From Qajar to Pahlavi. Iran 1919-1930. Lanham, MD, University Press of America, 2008, 462 p., index.
}

\author{
Bianca Devos
}

1 In his recent book, Majd undertakes the task of retelling the fundamental political changes in Iran during the 1920s, beginning with the Anglo-Persian Convention in 1919 and ending with Reḍa Šāh's "expanded reign of terror". The slightly larger first part of the book (chapters two to ten) recounts the events leading to the overthrow of the Qajjār monarchy and the establishment of the Pahlavi dynasty. The last five chapters focus on the consolidation of Reḍa šāh's rule and its increasingly dictatorial character, evident e.g. in his attacks on the Shi' $i$ clergy and the tribal population. The book follows Majd's previous publications in strongly emphasizing British influence on the events in Persia and making extensive use of American archival material. Most comparable with Oil and the Killing of the American Consul in Tehran (2006), he fills the pages with long quotations from records of the US State Department, reducing his own comments to at times half a sentence. Even though such a presentation does neither provide the adequate historical context nor a critical assessment of the sources, the author makes a valuable source accessible through his extensive verbatim citations. Since the cited correspondence often goes beyond a mere account of events, it also sheds light on social and cultural changes during the early Pahlavi period. Furthermore, the almost exclusively chronological order of the documents allows the reader to closely follow the course of events which were reported in a very detailed way from the perspective of diplomats representing American interests in the region. And finally, the appendant index is a helpful tool to directly consult the material for specific aspects. 
INDEX

Thèmes : 4.3. Histoire de l'Iran moderne (à partir de 1905)

\section{AUTEURS}

\section{BIANCA DEVOS}

Philipps-Universität Marburg 